\title{
IMAGE RETRIEVAL OBJECT GANESHA IMAGE USING INVARIANT MOMENT METHOD
}

\author{
${ }^{\mathrm{a}}$ Hendro Nugroho, ${ }^{\mathrm{b}}$ Eka Prakarsa Mandyartha \\ a,b Jurusan Teknik Informatika, Institut Teknologi Adhi Tama Surabaya \\ E-mail: dosh3ndro@gmail.com
}

\begin{abstract}
In the findings of the statue of Ganesha in Trowulan Mojokerto area is no longer intact, because the statue of Ganesha is found to have been on the surface of soil or underground, so the archaeologist is very difficult to categorize the findings. This research proposes to overcome the above problems it is necessary to the Image Retrieval system (image retrieval) that can provide information about the results of the discovery of such historic objects. For the image taken as Image Retrieval as an example of research trials is the Ganesha statue. From the Ganesha Statue is searched for feature extraction value by using Moment Invariant method, after which to get the result of image retrieval using Manhattan method. Image Retrieval information system work is image of Ganesa statue in preprocessing with size $200 \times 260$ pixel BMP, then image in edge detection using Roberts method and extraction of Moment Invariant feature and inserted into database as data training. For data testing the same process with data training so searched the closest distance using Manhattan method. From the results of 15 image testing statues Ganesha level to the accuracy of the true states there is $62 \%$ and stated wrong $38 \%$. Research can be further developed using various methods to improve image retrieval accuracy.
\end{abstract}

Keywords: The Statue of Arca Ganesha, Image Retrieval, Moment Invariant, Roberts Edge Detection, Manhattan 


\section{INTRODUCTION}

In the Trowulan area is one of the largest historical heritage of Majapahit kingdom in the archipelago. The findings encountered in the form of statues, temples, inscriptions, earthenware and metal tools. The statue that is often found is the statue of Ganesha because the Majapahit kingdom is a Hindu Shiva. Ganesa statue is found no longer intact because it has long surface on the ground or underground.

The Statue of Ganesha is one of the famous gods in Hinduism and much worshiped by Hindus, who have titles as Gods of knowledge and intelligence, Gods protectors, Gods of rejection/disasters and God of wisdom [1].

In this study used Image Retrieval process to determine the resemblance of the statue of Ganesha which is found in incomplete form with the data set of the statue of Ganesha that has been found. Image Retrieval is a process to get a number of images based on one image input [2]. The principle of image retrieval is the feature extraction of a number of objects have been stored in the database, then when an image is used as a query [3]. The feature will be calculated by distance to the features of all objects contained in the database. The result of this distance is often called a ranking [2].

Image retrieval can be divided into two types: context-based and content-based. Retrieval of content-based images refers to image features such as colors, textures, shapes, sematics or sensations they cause [4].

Image retrieval using good feature extraction for scaling, rotation, affine, and linear transformation images using the Invariant Moment method [5]. Moment Invariant on the image is used in the classification and pattern matching because the Manual Moment Invariant effectively provides image content information [5].

The Moment Invariant algorithm has been known as one of the most effective methods for extracting descriptive features. In essence, the algorithm produces the characteristic properties of objects from binary images [6]. To get a binary image object can use edge detection. Edge detection can be used to further sharpen the image structure. If an object uses this structure information, it will actually capture the structure information and will be a valid measure and evaluate the integrity of the structure to make the image more meaningful [6].

\section{IMAGE RETRIEVAL USING INVARIANT MOMENT}

This section explains about Image Retrieval, Edge Detection, Moment Invariant definitions and Manhattan distance calculations. The development of the image retrieval system is expected to be used as a reference for future research in the study of pattern recognition of the statue of Ganesha.

\section{Image Retrieval}

Image retrieval is the process of getting a number of imagery based on the image input [2]. The more specific term is content based image retrieval (CBIR) or image retrieval based on its content [2]. The term was first proposed by Kato in 1992 [7].

The image retrieval system can be divided into two types: context-based and contentbased content [4]. Content-based image retrieval system refers to image features such as colors, textures, shapes, semantics or sensations they cause [4].

The principle of image retrieval is the feature of a number of objects have been stored in the database, then when an image is used as a query material, the feature will be calculated after the pre-processing and segmentation [2]. Features obtained compared to the features of all objects contained in the database, through the calculation of the distance of the feature [2]. The result of this distance is often referred to as a score or ranking [2].

\section{Edge Detection}

In previous research, some popular edge detection algorithms (Roberts, Prewitt, Sobel, LoG and Canny) were used for texture analysis process [8].

Many studies argue that the structure of the image consists of the edges of the visible objects in the structure of the image can still be observed even though the image changes in scale [6]. 
In previous studies using edge detection was Hocenski's study, et al. In 2006 with visual inspection part of automation system [9]. Research Ali, et al. In 2001 boundary object by selecting the remote sensing image feature [10]. Research Pirzada, et al. In 2013 feature extraction from images taken by satellite [11]. And Bao's research, et al. In 2013, the extraction of medical image characteristics [12].

Based on previous research, this research uses Robert edge detection operator which has a fast and simple structure [8][13]. The Robert edge detection operator has a $2 \times 2$ convolution kernel and as shown in Figure 1 both convolution kernels are rotated $90^{\circ}$ to each other.

\begin{tabular}{|c|c|}
\hline 1 & 0 \\
\hline 0 & -1 \\
\hline
\end{tabular}$\quad$\begin{tabular}{|c|c|}
\hline 0 & 1 \\
\hline-1 & 0 \\
\hline
\end{tabular}

Figure 1. Kernel Robert

The kernel as shown in Figure 1 is set in the order in the image and then the edge image is obtained by the count of two results [8].

\section{Moment Invariant}

The moment invariant feature is useful for declaring objects by calculating object areas [2]. This feature uses a basic moment of a normalized center [2][14]. The resulting Moment can be used to handle translation, scaling, and rotating images [2][5].

Central Moment is the spatial moment calculated relative to the center of mass [2]. If the center of mass is $(\bar{y}, \bar{x})$. The central moment is written by Equation 1 .

$$
\mu_{i j}=\sum_{x=1}^{M} \sum_{y=1}^{N}(x-\bar{x})^{i}(y-\bar{y})^{j} I(x, y)
$$

In order for the central moment to be free of translation, scaling, and rotation it needs to be normalized [2]. Normalized center moments can be written in Equation 2.

$$
\eta_{i j}=\frac{\mu_{p q}}{\mu^{\gamma}{ }_{00}}, \gamma=\frac{i+j+2}{2}
$$

Creator, $\mathrm{Hu}$ creates seven moment Invariant written with Equation 3 [2][15]. These seven invariant moments will become the reference in this research as the extrusion of feature form on the statue of Ganesha.

$$
\begin{aligned}
& \emptyset_{1}=\eta_{20}+\eta_{02} \\
& \emptyset_{2}=\left(\mathrm{y}_{20}-\mathrm{y}_{02}\right)^{2}+\left(2 \mathrm{y}_{02}\right)^{2} \\
& \emptyset_{3}=\left(\mathrm{y}_{30}-3 \mathrm{y}_{12}\right)^{2}+\left(\mathrm{y}_{03}-3 \mathrm{y}_{21}\right)^{2} \\
& \text { (12.15) } \\
& \emptyset_{4}=\left(\mathrm{y}_{30}+\mathrm{\eta}_{12}\right)^{2}+\left(\mathrm{\eta}_{03}+\mathrm{\eta}_{21}\right)^{2} \\
& \emptyset_{5}=\left(\mathrm{y}_{30}-3 \mathrm{\eta}_{12}\right)\left(\mathrm{y}_{30}+\mathrm{\eta}_{12}\right)\left[\left(\mathrm{\eta}_{30}+\mathrm{y}_{12}\right)^{2}\right. \\
& \left.-3\left(\mathrm{y}_{21}+\mathrm{y}_{03}\right)^{2}\right]+ \\
& \left(y_{03}-3 y_{12}\right)\left(y_{03}+\eta_{21}\right)\left[\left(y_{03}+\eta_{12}\right)^{2}\right. \\
& \left.-3\left(\eta_{12}+\eta_{30}\right)^{2}\right] \\
& \emptyset_{6}=\left(\mathrm{y}_{20}-\mathrm{y}_{02}\right)\left[\left(\mathrm{y}_{30}+\mathrm{y}_{12}\right)^{2}-\left(\mathrm{y}_{21}+\mathrm{y}_{03}\right)^{2}\right]+ \\
& 4 \eta_{11}\left(\eta_{30}+\eta_{12}\right)\left(\eta_{03}+\eta_{21}\right) \\
& \emptyset_{7}=\left(3 \mathrm{y}_{21}-\mathrm{y}_{03}\right)\left(\mathrm{y}_{30}+\mathrm{y}_{12}\right)\left[\left(\mathrm{y}_{30}+\mathrm{y}_{12}\right)^{2}\right. \\
& \left.-3\left(\mathrm{y}_{21}+\mathrm{y}_{03}\right)^{2}\right] \\
& \left(\mathrm{y}_{30}-3 \mathrm{\eta}_{12}\right)\left(\mathrm{y}_{21}+\mathrm{y}_{03}\right)\left[\left(\mathrm{y}_{03}+\mathrm{y}_{21}\right)^{2}\right. \\
& \left.-3\left(\mathrm{y}_{30}+\mathrm{y}_{12}\right)^{2}\right]
\end{aligned}
$$

\section{The Calculation of Manhattan Distance}

The method of measuring the similarity distance for image retrieval using the Manhattan method is often called the City Block Method. Manhattan is a form of the Minkowski method, for which Manhattan uses value [16]. Then the Manhattan Equation can be written in Equation 4.

$$
M=\sum_{i=1}^{m} \sum_{j=1}^{n}\left|x_{i, j}-y_{i, j}\right|
$$

\section{SYSTEM OVERVIEW}

In the framework of research for Image Retrieval system can be explained the existence of two process that is process of training and testing process. In the data intercession training image input is done by the process of preparing the image size in the form of pixel units and black image background to make it easy to distinguish the background and image foreground The next process is done image grayscale process to Roberts edge detection, after obtaining the image of the edge of the statue Ganesha performed form feature extraction process using the Moment Invariant method to get the extraction features of the form values entered into the database.

The testing process for preprocessing, edge detection and extraction features are the same way as the testing process, but next to Image Retrieval is a process of calculating the distance between data training in the database with data testing using Manhattan method to get the 
selection of image results. Image Retrieval system design can be seen in Figure 2.

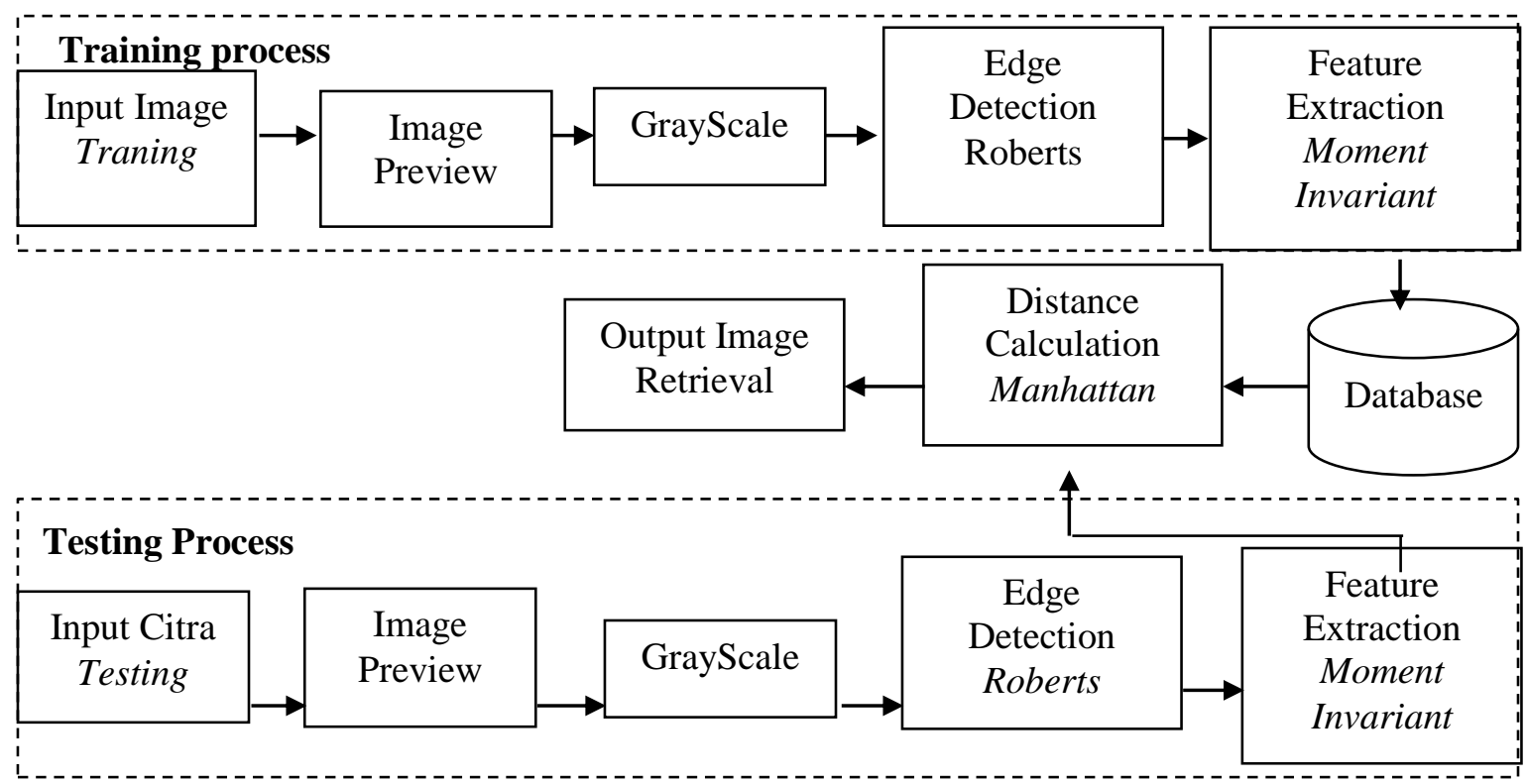

Figure 2. Image Retrieval System

\section{Image Preview}

Image preview is done to change the image in the form of BMP files and image size in the form of 200x260 pixels. For background image of Ganesha statue in the form of black color is used to facilitate the process of edge detection and extraction feature image form statue Ganesha.

\section{GrayScale Image}

This grayscale type image handles gradations of black and white that produce a gray color effect [2]. In the grayscale image, the color is expressed in intensity. In this case, the intensity ranges from 0 to 255 [2].

\section{Edge Detection Using Roberts Method}

After the image converted in the form of grayscale image, the image is done Roberts edge detection process to get the shape of the statue of Ganesha.

From the results of the detection of Robert's edge can be seen in Figure 5. The results on Roberts edge detection are strongly affected by noise, thus providing weak responses to the edge.

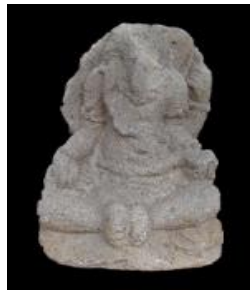

(a)

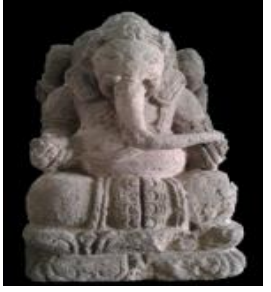

(b)
Figure 3. An example of the image of a statue of Ganesha (a) an incomplete Ganesha statue; (b) the statue of Ganesha is found still intact

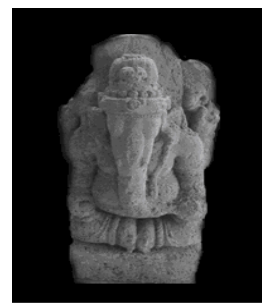

Figure 4. Grayscale Image Statue Ganesha

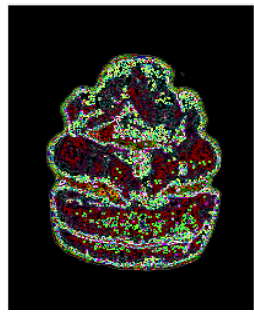

Figure 5. Ede Detection Roberts Statue Ganesha 
Table 1. Design of Data Tranning in Database

\begin{tabular}{clll}
\hline No & Field Name & Field Type & Field Size \\
\hline 1 & Nama Citra & Text & 255 \\
2 & M1 & Number & Double \\
3 & M2 & Number & Double \\
4 & M3 & Number & Double \\
5 & M4 & Number & Double \\
6 & M5 & Number & Double \\
7 & M6 & Number & Double \\
8 & M7 & Number & Double \\
9 & Ket & Text & 255 \\
\hline
\end{tabular}

\section{Feature Extraction Moment Invariant}

The use of Moment Invariant method for extraction of Ganesha statue image using seven Moment Invariant in Equation 3. The use of seven Moment Invariant is used to determine vector moment variable center on image of Ganesha statue.

\section{Data Storage Feature Extraction In The Database}

To facilitate the data storage of training used data storage media in the database. The database used is Microsoft Access with a design that can be seen in Table 1 .

\section{Distance Calculation Manhattan}

To get the results of Image Retrieval done calculation of data training with data testing, where the data Training stored in the database is done distance calculation by data testing using Manhattan method. After obtaining the value between data training with data testing with Equation 4, then ordering the smallest data to the largest of the value of the calculation of data distance training and data testing. To get a good accuracy value taken three image data image retrieval.

\section{RESULT AND DISCUSSION}

\section{Mechanical Testing}

The data used for testing is the incomplete Ganesha statue of 15 images of 35 images of the Ganesha statue intact. So the total image that will be used as tranning and testing a number of 50 images of the statue of Ganesha. Ganesha image retrieval that is not intact as data testing used for image retrieval is to get the shape and characteristic of the statue of Ganesha.

From the image retrieval result, three images with the smallest order value of Manhattan distance counting result.

\section{Testing Result}

The result of Ganesha image testing done by image retrieval system process is obtained from Ganesha image input which is not intact. An example of an incomplete Ganesha image input and three image results from the image retrieval can be seen in Figure 6.

The results obtained from the image retrieval system shown in Figure 6, there are three images of ganesha statues that have the same characteristics with the image of Ganesha statue input is the sitting position of the two soles meet or face (Utkutikasana).

In addition to the position of sitting statues Ganesha also described similarities other features between the image of the statue Ganesha image with the results of three images of the statue of Ganesha is depicted humanheaded elephant head, wearing Hara sumping (necklace), upawita and belt, buckle bun, wide ear, four hands wear kankana Bracelet), fourhanded with a two-handed position on the right hand holding an ivory fracture and the left holding modaka (bowl), while two righthanded axes hold the ax and the left hold aksamala (tasbih), the trunk's position sucking into the bowl, and the second Feet wearing bracelet.

Table 2 describes the extraction value of the Moment Invariant feature on the Ganesha statue image data imaging performed by Manhattan distance calculation with the data training in the database. The results of the calculation of the overall distance of the database database is done by the smallest data to get the output data retrieval image of Ganesha statue that is similar to the statue of Ganesha input. 


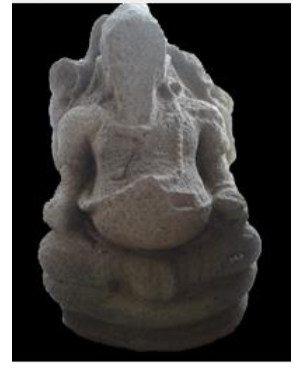

(a)

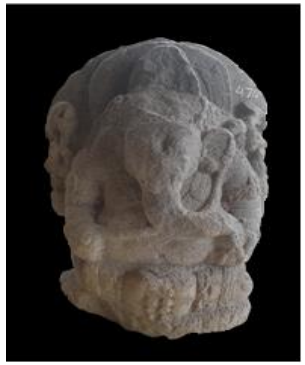

(b)

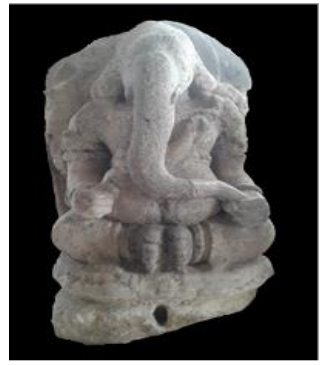

(c)

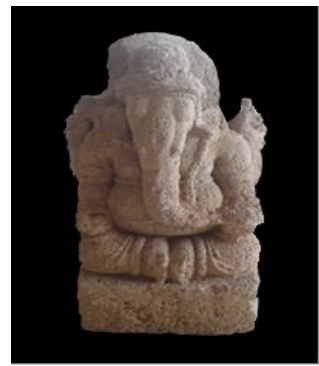

(d)

Figure 6. (a) Input of Ganesha statue image; (b) Image retrieval result of Ganesha statue 1; (c) Results of Image Retrieval statue of Ganesha 2; (d) Image Results Retrieval statue Ganesha 3

Table 2. Extraction Result Feature Moment Invariant Image Data Testing Arca Ganesha

\begin{tabular}{cccccccc}
\hline Name Image & \multicolumn{7}{c}{ Extrusion Value Moment Invariant Feature } \\
\cline { 2 - 8 } Input & M1 & M2 & M3 & M4 & M5 & M6 & M7 \\
\hline Patung_ganesa38 & 0.643571 & 0.045432 & 0.0003413 & 0.001675 & $-4 \mathrm{E}-6$ & 0.000356 & $-3 \mathrm{E}-6$ \\
\hline
\end{tabular}

Table 3. Manhattan Distance Results

\begin{tabular}{lll}
\hline No & Name Image Output & Distance Value \\
\hline 1 & Patung_ganesa42 & 0.013274 \\
\hline 2 & Patung_ganesaa39 & 0.09344 \\
\hline 3 & Patung_ganesa40 & 0.094568 \\
\hline
\end{tabular}

The result of Manhattan distance calculation value between the image input with the name of the ganesha statue can be seen in table 3 which is sorted from the smallest value and taken the three smallest value of the overall value.

The results of all 15 Ganesha statue image testing data can be seen in Table 4 as the result of Manhattan distance count and table 5 as the material of characteristic analysis from Ganesha statue to calculate the success rate.

\section{Analysis of Test Result}

The test data compares the characteristics of the input image and the three output image results consisting of the sitting position of the statue of Ganesha and the number of Ganesha statues. The results obtained from the test were $62 \%$ (sixty percent) stated true and 38\% (thirty eight percent) stated incorrectly out of a total of 90 (ninety) characteristics of the output image.

Table 6 describes the results of testing accuracy on Ganesha statue image. For analysis the results obtained are influenced by the image of input testing which suffered severe damage to the ganesha statue (Figure 7), where there is damage to the loss of hands, head, or feet caused by nature or fandalism.

The image of Ganesha statue input that suffered severe damage was declared as data testing used as an analysis material for arkelogi to analyze the amount of damage and analyze the type of statue Ganesha for further research. If the initial reconstruction of the statue Ganesha damaged can be compared with the three statues Image Retrieval Output so that it can describe the origin of the statue Ganesha.

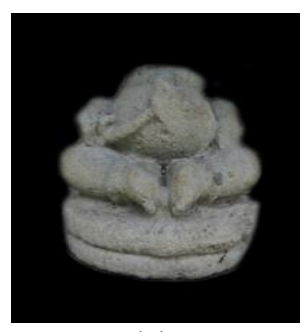

(a)

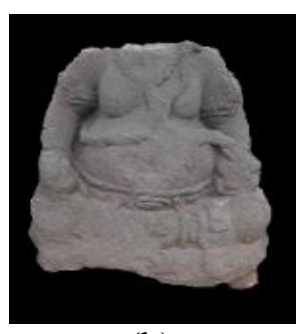

(b)
Figure 7. (a) The Ganesha statue is missing head and hand; (b) Ganesha statue is missing head and legs

\section{CONCLUSION}

The conclusion of Gansha image retrieval system is the result that affect the accuracy of the image retrieval using Moment Invariant method is the image of Ganesha statue input which suffered severe damage that is on hand, head or leg.

For good Ganesha statue input that is still the form of hands, feet or head then the accuracy is very high. 
Table 4. Manhattan Distance Calculation (JAM) On Ganesha Testing and Training Arca

\begin{tabular}{llllllll}
\hline \multirow{2}{*}{ No } & Name Image & \multicolumn{7}{c}{ Results Image Retrieval } \\
\cline { 3 - 7 } & Input & Image 1 & JM1 & Image 2 & JM 2 & Image 3 & JM3 \\
\hline 1 & Patung_ganesa48 & Patung_ganesa36 & 0.068 & Patung_ganesa34 & 0.110 & Patung_ganesa30 & 0.118 \\
\hline 2 & Patung_ganesa49 & Patung_ganesa22 & 0.413 & Patung_ganesa16 & 0.526 & Patung_ganesa25 & 0.537 \\
\hline 3 & Patung_ganesa44 & Patung_ganesa26 & 0.0808 & Patung_ganesa23 & 0.095 & Patung_ganesa36 & 0.113 \\
\hline 4 & Patung_ganesa47 & Patung_ganesa29 & 0.089 & Patung_ganesa40 & 0.126 & Patung_ganesa34 & 0.146 \\
\hline 5 & Patung_ganesa43 & Patung_ganesa41 & 0.034 & Patung_ganesa39 & 0.056 & Patung_ganesa37 & 0.056 \\
\hline 6 & Patung_ganesa50 & Patung_ganesa41 & 0.057 & Patung_ganesa40 & 0.105 & Patung_ganesa39 & 0.115 \\
\hline 7 & Patung_ganesa6 & Patung_ganesa21 & 0.566 & Patung_ganesa42 & 0.858 & Patung_ganesa8 & 0.091 \\
\hline 8 & Patung_ganesa28 & Patung_ganesa40 & 0.038 & Patung_ganesa42 & 0.056 & Patung_ganesa41 & 0.081 \\
\hline 9 & Patung_ganesa27 & Patung_ganesa40 & 0.108 & Patung_ganesa42 & 0.220 & Patung_ganesa41 & 0.278 \\
\hline 10 & Patung_ganesa20 & Patung_ganesa17 & 0.0489 & Patung_ganesa42 & 0.061 & Patung_ganesa8 & 0.088 \\
\hline 11 & Patung_ganesa33 & Patung_ganesa31 & 0.048 & Patung_ganesa35 & 0.061 & Patung_ganesa32 & 0.077 \\
\hline 12 & Patung_ganesa4 & Patung_ganesa7 & 0.035 & Patung_ganesa18 & 0.039 & Patung_ganesa12 & 0.068 \\
\hline 13 & Patung_ganesa45 & Patung_ganesa36 & 0.092 & Patung_ganesa32 & 0,094 & Patung_ganesa23 & 0.102 \\
\hline 14 & Patung_ganesa46 & Patung_ganesa23 & 0.092 & Patung_ganesa30 & 0.094 & Patung_ganesa36 & 0.102 \\
\hline 15 & Patung_ganesa38 & Patung_ganesa42 & 0.0132 & Patung_ganesa39 & 0.093 & Patung_ganesa40 & 0.094 \\
\hline
\end{tabular}

Table 5. Data Testing Results Based on Characteristics of Ganesha Arca

\begin{tabular}{|c|c|c|c|c|c|c|c|c|}
\hline \multirow{3}{*}{$\begin{array}{l}\mathbf{N} \\
\mathbf{o}\end{array}$} & \multirow{3}{*}{$\begin{array}{l}\text { Name Image } \\
\text { Input }\end{array}$} & \multirow{3}{*}{$\begin{array}{l}\text { Input Image } \\
\text { Feature }\end{array}$} & \multicolumn{6}{|c|}{ Results Image Retrieval } \\
\hline & & & \multicolumn{3}{|c|}{ Image Feature Position } & \multicolumn{3}{|c|}{$\begin{array}{c}\text { Number of } \\
\text { Image Hand }\end{array}$} \\
\hline & & & 1 & 2 & 3 & 1 & 2 & 3 \\
\hline 1 & Patung_ganesa48 & Utkutikasana,Tangan 4 & Utkutikasana & Utkutikasana & Utkutikasana & 4 & 2 & 4 \\
\hline 2 & Patung_ganesa49 & Utkutikasana,Tangan 2 & Utkutikasana & Utkutikasana & Utkutikasana & 2 & 4 & 4 \\
\hline 3 & Patung_ganesa44 & Utkutikasana,Tangan 4 & Utkutikasana & Utkutikasana & Utkutikasana & 4 & 4 & 4 \\
\hline 4 & Patung_ganesa47 & Utkutikasana,Tangan 2 & Utkutikasana & Utkutikasana & Utkutikasana & 2 & 4 & 2 \\
\hline 5 & Patung_ganesa43 & Utkutikasana,Tangan 2 & Utkutikasana & Utkutikasana & Utkutikasana & 4 & 4 & 4 \\
\hline 6 & Patung_ganesa50 & Utkutikasana,Tangan 2 & Utkutikasana & Utkutikasana & Utkutikasana & 4 & 4 & 4 \\
\hline 7 & Patung_ganesa6 & $\begin{array}{l}\text { Utkutikasana,Tangan } \\
\text { hilang }\end{array}$ & Utkutikasana & Utkutikasana & Utkutikasana & 4 & 4 & 4 \\
\hline 8 & Patung_ganesa28 & $\begin{array}{l}\text { Utkutikasana,Tangan } \\
\underline{\text { Hilang }}\end{array}$ & Utkutikasana & Utkutikasana & Utkutikasana & 4 & 4 & 4 \\
\hline 9 & Patung_ganesa27 & $\begin{array}{l}\text { Utkutikasana,Tangan } \\
\underline{\text { Hilang }}\end{array}$ & Utkutikasana & Utkutikasna & Utkutikasana & 4 & 4 & 4 \\
\hline 10 & Patung_ganesa20 & Stanka, Tangan 4 & Utkutikasana & Utkutikasana & Utkutikasna & 4 & 4 & 4 \\
\hline 11 & Patung_ganesa33 & Utkutikasana,Tangan 4 & Utkutikasana & Utkutikasana & Utkutikasana & 4 & 4 & 4 \\
\hline 12 & Patung_ganesa4 & Tangan 4,Kaki hilang & Utkutikasana & Utkutikasana & Ardhaparyankasana & 4 & 4 & 4 \\
\hline 13 & Patung_ganesa45 & Utkutikasana,tangan 2 & Utkutikasana & Utkutikasana & Utkutikasana & 4 & 4 & 4 \\
\hline 14 & Patung_ganesa46 & Utkutikasana,tangan 2 & Utkutikasana & Utkutikasana & Utkutikasana & 4 & 4 & 4 \\
\hline 15 & Patung_ganesa38 & Utkutikasana,Tangan 4 & Utkutikasana & Utkutikasana & Utkutikasana & 4 & 4 & 4 \\
\hline
\end{tabular}


Table 6. The Results of Testing Accuracy on Ganesha Statue Image

\begin{tabular}{|c|c|c|c|c|}
\hline \multirow{2}{*}{ No } & \multirow{2}{*}{$\begin{array}{l}\text { Name Image } \\
\text { Input }\end{array}$} & \multicolumn{2}{|c|}{ Analysis Result } & \multirow{2}{*}{$\begin{array}{c}\text { Degree } \\
\text { of } \\
\text { Accuracy }\end{array}$} \\
\hline & & True & Wrong & \\
\hline 1 & Patung_ganesa48 & 5 & 1 & $83 \%$ \\
\hline 2 & Patung_ganesa49 & 4 & 2 & $67 \%$ \\
\hline 3 & Patung_ganesa44 & 6 & 0 & $100 \%$ \\
\hline 4 & Patung_ganesa47 & 5 & 1 & $83 \%$ \\
\hline 5 & Patung_ganesa43 & 3 & 3 & $50 \%$ \\
\hline 6 & Patung_ganesa50 & 3 & 3 & $50 \%$ \\
\hline 7 & Patung_ganesa6 & 3 & 3 & $50 \%$ \\
\hline 8 & Patung_ganesa28 & 3 & 3 & $50 \%$ \\
\hline 9 & Patung_ganesa27 & 3 & 3 & $50 \%$ \\
\hline 10 & Patung_ganesa20 & 3 & 3 & $50 \%$ \\
\hline
\end{tabular}

\section{REFERENCES}

[1] "Ganesa," Wikipedia bahasa Indonesia, ensiklopedia bebas. 2017.

[2] A. Kadir and A. Susanto, "Teori dan aplikasi pengolahan citra," Yogyak. Andi, 2013.

[3] P. A. Hemalatha, K. S. Ravich, and B. Santhi, "Query By Image Content using Discrete Cosine Transform," 2013.

[4] S. N. Endah, "Content Based Image Retrieval Using Expression Sentivity By Fuzzy Inference System," Kursor, vol. 8, no. 1, pp. 21-32, 2015.

[5] A. Amanatiadis, A. Gasteratos, S. A. Chatzichristofis, and E. G. Karakasis, "Image Moment Invariants as Local Features for Content Based Image Retrieval using the Bag-of-Visual-Words Model,” 2015.

[6] P. Premaratne and M. Premaratne, "Image matching using moment invariants," Neurocomputing, vol. 137, pp. 65-70, 2014.

[7] Zhang D., "Image Retrieval Based Shape." Unpublished Dissertation, 2002.

[8] Ş. Öztürk and B. Akdemir, "Comparison of edge detection algorithms for texture analysis on glass production," Procedia-Soc. Behav. Sci., vol. 195, pp. 2675-2682, 2015.

[9] Z. Hocenski, S. Vasilic, and V. Hocenski, "Improved canny edge detector in ceramic tiles defect detection," in IEEE Industrial Electronics, IECON 2006-32nd Annual Conference on, 2006, pp. 3328-3331.

[10] M. Ali and D. Clausi, "Using the Canny edge detector for feature extraction and

\begin{tabular}{|c|c|c|c|c|}
\hline 11 & Patung_ganesa33 & 3 & 3 & $50 \%$ \\
\hline 12 & Patung_ganesa4 & 3 & 3 & $50 \%$ \\
\hline 13 & Patung_ganesa45 & 3 & 3 & $50 \%$ \\
\hline 14 & Patung_ganesa46 & 3 & 3 & $50 \%$ \\
\hline \multirow[t]{2}{*}{15} & Patung_ganesa38 & 6 & 0 & $100 \%$ \\
\hline & Total & 56 & 34 & 90 \\
\hline \multicolumn{2}{|c|}{ Degree of Accurancy } & 62 & $38 \%$ & \\
\hline
\end{tabular}

\section{ACKNOWLEDGMENT}

The author would like to thank the Menristekdikti (Minister of Research and Technology for Higher Education Republic of Indonesia) for his financial support in the form of PDP Grants (Research Lecturer Beginner).

enhancement of remote sensing images," in Geoscience and Remote Sensing Symposium, 2001. IGARSS'01. IEEE 2001 International, 2001, vol. 5, pp. 2298-2300.

[11] S. J. H. Pirzada and A. Siddiqui, "Analysis of edge detection algorithms for feature extraction in satellite images," in Space Science and Communication (IconSpace), 2013 IEEE International Conference on, 2013, pp. 238-242.

[12] C. Bao and C. Sheng, "A parameterized logarithmic image processing method based on Laplacian of Gaussian filtering for lung nodules enhancement in chest radiographs," in Instrumentation and Measurement, Sensor Network and Automation (IMSNA), 2013 2nd International Symposium on, 2013, pp. 649652.

[13] L. G. Roberts, "Machine perception of threedimensional solids," Massachusetts Institute of Technology, 1963.

[14] L. Diao, J. Peng, J. Dong, and F. Kong, "Moment invariants under similarity transformation," Pattern Recognit., vol. 48, no. 11, pp. 3641-3651, 2015.

[15] S. Theodoridis, Pattern Recognition. San Diego: Academic Press, 2006.

[16] Arif Muntasa, Pengenalan Pola, Aplikasi Pengenalan Wajah, Analisis Tekstur Obyek, Pengenalan Plat Nomer Kendaraan, dan Pembulu Darah, Ed. 1. Yogyakarta: Graha Ilmu, 2015. 